\title{
Kenny-Caffey Syndrome Type 2
}

National Cancer Institute

\section{Source}

National Cancer Institute. Kenny-Caffey Syndrome Type 2. NCI Thesaurus. Code C130993.

An autosomal dominant form of Kenny-Caffey Syndrome due to mutation(s) in the FAM111A gene, encoding protein FAM111A. This condition is characterized by transient hypocalcemia, delayed closure of the anterior fontanel, eye anomalies, including microphthalmia, proportionate short stature, and cortical thickening and medullary stenosis of the tubular bones. 